\title{
A szankciók mint a nyomásgyakorlás eszközei a nemzetközi kapcsolatokban: a Közel-Kelet és Irán esete
}

\author{
Sanctions As Means of Exerting Pressure in International \\ Relations: the Case of the Middle East and Iran
}

Csicsmann László

https://doi.org/10.47707/Kulugvi Szemle.2021.3.3

Összefoglaló: Az elmúlt évtizedekben a nagyhatalmak által alkalmazott szankciós rendszer jelentősen átalakult. A kezdetleges, általánosabb hatású intézkedéseket a célzott és az ún. okos szankciók váltották fel. A jelen tanul mány - a bevezető elméleti gondolatokat követően - a közel-keleti térség egyes országain (Líbián, Szírián, Szudánon és legfőképp az iráni esettanulmányon) keresztül vizsgálja a szankciós politika múltját és jelenét. E nyomásgyakorlás hatékonyságáról és annak méréséről a szakirodalomban hatalmas vita folyik. Az Iránt érintő szankciókat több hullámban vezették be az iráni iszlám forradalmat, illetve a 2001. szeptember 11-i terrortámadást követően. A 2015 ben aláírt nukleáris megállapodás azt az ígéretet hordozta a perzsa állam szá mára, hogy a főbb korlátozások betartása esetén azokat fokozatosan feloldják. 2018-ban azonban a Trump-adminisztráció egyoldalúan felrúgta a nukleáris alkut, és az ún. maximális nyomás politikájának keretében minden addiginál súlyosabb intézkedéseket vezetett be. Irán minderre az ún. maximális ellenállás politikájával válaszolt, amelynek következtében a gazdaság válságba került ugyan, ám 2020-ra az alkalmazkodás sikeressége is láthatóvá vált. Az Iránnal szembeni intézkedések így egyrészt elérték a hatásukat, hiszen az ország olaj exportja jelentősen csökkent, másrészt azonban a rezsim ettől nem omlott össze. Mindez a szankciós politika korlátaira és lehetôségeire is rámutat.

Kulcsszavak: maximális nyomás, Irán, Közel-Kelet, Líbia, okos szankciók. másodlagos szankciók, nukleáris megállapodás

Abstract: During the recent decades, the sanctions imposed by great powers have transformed. The initial, general sanctions have replaced by the targeted 


\section{Külïgyi Szemle}

and smart measures. The aim of this study is to explore - after the introductory theorelical considerations - the history and the present of the sanctions policy through the individual cases of the Middle Eastern countries Libya, Syria. Sudan, and a special allention has been paid on the Iranian case). There has been a continuous professional debate about the effectiveness of the sanctions and how to measure it. The sanctions imposed on Iran has been introduced in several waves after the Islamic Revolution as well as after the 9/11 terror attack. The promise of the nuclear deal for the Persian stale, which was signed in 2005 , was the gradual lifting of sanctions after implementation. However, in 2018 the Trump administration unilaterally abandoned the nuclear deal, and it has reimposed the sanctions through the policy of "maximum pressure". Iran's response was the "maximum resistance" policy, the country's economy is in crisis; however, in 2020 the first signs of adaptation to the sanctions have appeared. On the one hand, the measures imposed on Iran have met with the goals as the oil export of the country has significantly decreased. On the other hand, the Iranian regime has not collapsed, but survived. It shows the limits and potentials of the sanctions policy.

Keywords: maximum pressure, Iran, Middle East, Libya, smarl sanclions, secondary sanctions, nuclear agreement

\section{A szankciókról általában}

Az államok közötti kapcsolatok egyik velejárója, hogy egyes szereplők bizonyos magatartások kikényszerítése vagy azok elhagyása érdekében a nyomásgyakorlás politikai vagy gazdasági eszközeihez, vagyis a szankciókhoz nyúlnak. Azok alkalmazásának a célja általában kettős: egyrészt lehet büntetés valamilyen típusú - nem a nemzetközi normáknak megfelelő - magatartás következtében, másrészt annak a módja, hogy rávegye a szankcionált államot a normák követésére (Galtung, 1967, 378-416. o.). A szankciók alkalmazása a 20. században vált általánossá, és a hatalmi viszonyokban a felsô pozíciót elfoglaló államok használják a gyengébbekkel szemben. Az 1950-es évektől a nyugati világ, s azon belül is az Amerikai Egyesült Államok élt ezzel a lehetőséggel a leggyakrabban olyan államokkal szemben, amelyek a nemzetközi jog szabályait nem fogadták el, nem tartották magukra 
nézve kötelezőnek. Ezen államokat összefoglaló néven lator-vagy haramiaállamoknak nevezzüik; e kifejezés egyfajta bélyegnek tekinthető a globális vagy a regionális hatalmi viszonyokban domináns államok részéről. A század második fele azért is hozott jelentős fordulatot a szankciók történetében, mert a háborút mint a nemzetközi politika egyik eszközét jelentősen korlátozták, s így a fegyveres erő alkalmazásának az egyik megfelelő alternatívájává vált a szankciók bevetése.

A fentiekből következik, hogy a szankciók többféle alkalmazási formáját ismerjüik. Vannak az ún. bilaterális szankciók, amelyek keretében az egyik állam egy másik ellen vet be kényszerítő intézkedése ket. Erre jó példa az Egyesüilt Államok által Kuba ellenében 1958-ban bevezetett korlátozások. A multilaterális szankciók államok egy csoportja vagy nemzetközi szervezetek által gyakorolt büntető intézkedések. A nemzetközi szervezetek közül történelmileg kiemelkedik a Nemzetek Szövetsége, illetve a második világháború után az Egyesült Nemzetek Szervezete. Az utóbbi esetében fontos utalni a hidegháborús rivalizálásra is, amely némiképp korlátozta az öt állandó tag közötti egyetértést a büntetőintézkedések alkalmazása kapcsán. Az ENSZ mindössze egyszer döntött kötelező érvényű szankcióról (az akkori Rhodézia ellen) és egyszer nem teljes körú fegyverembargóról (a dél-afrikai apartheid rendszerrel szemben) (Kaempfer és Lowenberg, 2007, 868-911. o.).

1990 után, az ún. öbölválság kapcsán, a nemzetközi közösség Irak kal szemben egy szinte teljes körű gazdasági embargót épített ki, amelynek az elsődleges célja az volt, hogy helyreállítsák Kuvait szuverenitását. Az évtized folyamán, de még inkább a 2001. szeptember 11-i terrortámadást követően, az amerikai narratívában megjelent a korábban említett latorállamok (rogue states) kifejezés, s az érintett országokkal szemben Washington kétoldalú és multilaterális szankciórendszert egyaránt igyekezett alkalmazni. 


\section{Külïgyi Szemle}

\section{A szankciók hatékonysága}

A szakirodalomban a legnagyobb vita éppen arról folyik, hogy a szankciók elérik-e a céljukat, és mennyiben hatékonyak. A témával foglalkozó egyik legjelentősebb munka szerint a hatékonyság általában kifejezetten rossznak nevezhető (Hufbauer, Schott és Elliott, 1990). A kérdés persze az, hogy azt hogyan mérjük, hiszen annak a kvantifikálása meglehetősen bizonytalannak túnik. Például 1979-ben az arab országok felfüggesztették Egyiptomnak az Arab Államok Ligájában való tagságát. Az ország „kiközösítése” politikai jellegű büntetésnek tekinthető, mivel a legnépesebb arab állam volt az, amely (1979-ben, elsőként) elismerte Izrael Államot, és békeszerződést is kötött vele. A szankciók említett kettős célja - annak büntető jellege és egy adott magatartás kikényszerítése - kapcsán Egyiptom esetében kétséges eredményről számolhatunk be. Miközben a büntető jellegét betöltötte Egyiptom kizárása a szervezetből, érdemben az a békeszerződést nem érintette.

A szankciók hatékonysága vonatkozásában egy fontos kérdés, hogy ki(k) annak az alanya(i). Az intézkedések fejlődéstörténetében megjelentek az ún. okos szankciók (smart sanctions). Korábban ugyanis azok gyakran az egész társadalmat érintették, mégis kevéssé váltották be a hozzá füzött reményeket. Például az Irak ellen 1990-ben bevezetett szankciórendszer céljai között szerepelt a támadókapacitás csökkentése, s végső soron a rezsimváltás. Az eset a vonatkozó szakirodalomban jelentős vitát váltott ki, hiszen az súlyos humanitárius problémákat okozott (pl. növekedett a szegénység, és közvetetten ugyan, de az tehető felelőssé halálos áldozatokért is) (Boone, Gazdar és Hussain, 1997). Vajon van-e értelme széles társadalmi csoportokat érintő szankciókat kivetni úgy, hogy az intézkedések csak csekély valószínűséggel érik el a céljaikat?

Éppen a társadalmi károkból tanulva született meg a célzott szankciók (targeted sanctions) rendszere, amely a politikai és/vagy gazdasági elit bizonyos köreit sújtja. Ide tartozik például a bizonyos vezető személyekkel szembeni utazási korlátozások bevezetése, a politikai elit 
egyes tagjai vagyonának a befagyasztása. Ezek alkalmazásának cél ja, hogy a negatív humanitárius hatások kikerülésével egy célzott kör, az adott állam politikai és/vagy gazdasági elitjének bizonyos tagjait érintse. A korábban hivatkozott Johan Galtung fogalmazta meg, hogy kétségesnek tekinthető az ilyen jellegű szankciók hatása, sőt hozzá járulhatnak, hogy a büntetőintézkedések révén bizonyos társadalmi csoportok kedvezóbb helyzetbe kerüljenek (Galtung, 1967, 378-416. o.).

Egy, a gazdasági szankciók hatását elemző tanulmányból az de rül ki, hogy az általuk elérni kívánt cél és a hatékonyság/eredmény között fordított arányosság áll fenn. Ha egy állam vet ki egy másikkal szemben szankciót, az mindig kevésbé hatékony, mint a nemzetközi közösség jelentős részének a támogatását élvező, multilaterális kere tek között kiszabott intézkedések. Például, ha az egyik állam a másik ban rezsimváltást szeretne elérni, de azt a nemzetközi közösség nem támogatja, nem valószínú, hogy eléri a célját. A szankciók hatásával kapcsolatban azt is érdemes számításba venni, hogy azok - különö sen gazdasági vonatkozásban - az ún. „küildó állam” számára is hátrá nyokat okozhatnak. A gazdasági jellegű szankciók általában a bojkott vagy az embargó formáját öltik: az előbbi esetén bizonyos termékek vásárlásától tartózkodik a „küildő állam”, az utóbbi során pedig egyes termékek eladását akadályozza meg. Ha egy állam alkalmazza a boj kottot, annak elsősorban kereskedelemeltérítő hatása van, vagyis az ún. „célállam” más csatornákon szerez be vagy értékesít termékeket (Kaempfer és Lowenberg, 2007, 868-911. o.).

A gazdasági szankciókkal kapcsolatban az elmúlt évtized egyik legérdekesebb vitája Oroszországgal összefüiggésben alakult ki. A Krím félsziget 2014-es annexióját követően az Európai Unió gazdasági szankciókat vetett ki Moszkvával szemben, amelyek összességében inkább kereskedelemelterelő hatást váltottak ki. Egy tanulmány azt is megfogalmazza, hogy nem szabad összekeverni a szankciók hatását más, egyidejű gazdasági sokkokétól. Az orosz példa esetén elsősorban az olaj világpiaci árának esése, s nem a szankciók okoztak kellemet lenséget a gazdaság számára (Smeets, 2018). 


\section{Külïgyi Szemle}

\section{A Közel-Kelet és a szankeiók}

A tágabb közel-keleti térség (Middle East and Norlh Africa, a további akban: MENA) számos lehetőséget biztosít az elemző számára, hogy a politikai és gazdasági nyomásgyakorlás kérdéseit megvizsgálja. A MENA térségben ugyanis több olyan állam is található, amely a külpolitikájában és az ideológiájában egyaránt megkísérelt az Egyesült Államok által dominált liberális nemzetközi renddel szembeszállni. Ennek következtében elsősorban Washington alkalmazza a politikai és gazdasági nyomásgyakorlást, amelynek főbb eszközei az amerikai külpolitikában a következők:

- katonai segélyek befagyasztása;

- az államhoz köthető paramilitáris csoportok terroristává nyilvánítása;

- az adott országnak az Egyesült Államokban található pénzeszközeinek az átmeneti zárolása;

- a szankcionált állammal bármilyen gazdasági kapcsolatot ápo ló országok elleni büntetőintézkedések (ún. másodlagos szank ciók);

- egyes termékek vásárlásának a felfüggesztése;

- kereskedelmi blokád/embargó;

- gazdasági támogatás visszatartása;

- vezető személyekkel szembeni intézkedések (pl. beutazási kor látozások elrendelése);

- célzott dróntámadás terrorista személyek ellen;

- katonai beavatkozás;

- nemzetközi szervezeteken keresztüli nyomásgyakorlás.

Az Obama-éra alatt a közel-keleti ügyektól való egyfajta amerikai visszahúzódás vette kezdetét, ugyanakkor az USA továbbra is az egyik meghatározó szereplő maradt a térségben. A MENA régióra az ún. kompetitív multipolaritás jellemző, azaz az Egyesült Államok mellett három másik hatalom (Kína, Oroszország és az Európai Unió) is érdemben befolyásolja az eseményeket (Kausch, 2015). A térségben az 
Egyesült Államok vetette be a legnagyobb részt a politikai és gazdasági nyomásgyakorlás eszközeit, kisebb mértékben azonban a három másik szereplő is alkalmazta azokat.

Az amerikai külpolitikában az 1990-es években kialakult az ún. latorállam doktrína (rogue state doctrine), amely szerint az Egyesült Államok győztesen került ki a hidegháborúból ugyan, de a biztonságát olyan, elsősorban a fejlődő világhoz tartozó államok veszélyez tetik, amelyek Washingtonnal ellenséges magatartást tanúsítanak, így miattuk szüikséges magasan tartani a védelmi kiadásokat, hiszen a nemzetközi rendszer múködése a bipoláris világrend felbomlásával kiszámíthatatlanná vált (Eland, Lee, 2001). A doktrína küilönösen a Clinton-adminisztráció éveiben vált meghatározóvá, ugyanakkor a 2001. szeptember 11-i terrortámadás emelte azt az amerikai külpolitikai diskurzusban központi témává.

Érdemes leszögezni, hogy a közel-keleti államokkal szembeni szankciókat eltérő időben vezették be, ugyanakkor az említett folyamatok kétségkíviul hatottak a nyomásgyakorlás kiterjedésére. A 2001. szeptember 11-i terrortámadás kapcsán különösen három feltétele zés kapcsolódott össze az amerikai gondolkodásban: a latorállamok terrorista csoportokat támogatnak, és/vagy tömegpusztító fegyverek és ballisztikus rakéták beszerzésére törekednek, valamint a belpolitikájukban az elnyomás eszközeit alkalmazzák (Homolar, 2011, 712. o.). A latorállamokkal kapcsolatos narrativa a Reagan-korszak alatt már megjelent, és a következő országokat sorolták közéjük: Irán, Líbia, Észak-Korea, Kuba és Nicaragua. Az ifjabb George Bush 2002. január 30-án, az Unió helyzetéről szóló beszédében használta először a „gonosz tengelye" kifejezést (axis of evil speech), s Irakot, Iránt és ÉszakKoreát sorolta a terrorizmust támogató és tömegpusztító fegyverek szerzésére törekvő államok csoportjához. Más beszédekben (küiönösen Donald Rumsfeld védelmi miniszter) esetenként további államokat - így az általunk vizsgálandó közel-keleti térségből Líbiát, Szíriát és Szudánt - is említenek. Az utolsó annyiban kivételnek tekinthető, hogy tömegpusztító fegyverek beszerzésére nem törekedett. A tágabb 


\section{Külïgyi Szemle}

közel-keleti térség 24+1 államából' öt olyan van (Irak, Irán, Líbia, Szí ria és Szudán), amellyel szemben az amerikai külpolitika a politikai és gazdasági nyomásgyakorlás eszközeit alkalmazta.

A szankciókat elsődlegesen az amerikai külpolitika alkalmazza ugyan, és ennek oka az Egyesült Államok által vizionált világkép, mégis esetenként a másik három külső szereplő, sőt a regionális és a globális szintű nemzetközi szervezetek is élnek ilyen jellegű eszközökkel. A tanulmány a következőkben röviden bemutatja a három MENA tér ségbeli állammal (Líbia, Szíria és Szudán) kapcsolatos szankciórend szert, majd esettanulmányként a fenti elméleti kereteknek megfele lően elemzi az iráni esetet, amelyben talán nemesak a régión belül, de globálisan is az egyik legkomplexebb nyomásgyakorló rendszernek lehetünk a tanúi, és történelmileg az 1979-es iráni iszlám forradalomhoz köthető. A tanulmány mindegyik ország kapesán reflektál a fenti ekben bemutatott elméleti vitákra is, különösen a szankciók hatékony ságával és céljaival kapcsolatban. Az elemzés azonban nem tér ki az iraki szankciókra, ugyanis 2003 márciusában az Egyesült Államok és szövetségesei ott katonai beavatkozással kényszerítették ki a rezsim váltást. Az iraki kérdés rendkíviul komplex, ugyanakkor a szakiroda lomban is viszonylag részletesebben feldolgozták már (Wallensteen, Staibano és Eriksson, 2005).

Ehelyütt arra is érdemes felhívni a figyelmet, hogy éppen a szeptember 11-i terrortámadás következtében erősödött meg az amerikai külpolitikai diskurzusban és gyakorlatban az ún. rezsimváltás elmélete, amely túlmutat a szankciók alkalmazásán. Ez utóbbinak az egyik célja a nem együittmúködô rezsim leváltása lehet, mégis elsősorban a katonai intervencióhoz kötődik. A felsorolt közel-keleti latorállamok közül kettő ellen is alkalmazta azt a nemzetközi közösség: Irakban 2003-ban és Líbiában 2011-ben. Továbbá egyes államok területén (lásd Szíria) az USA és más országok a terrorista szervezetek (Iszlám

1 Azaz az Arab Államok Ligájának 22 tagja, a két nem arab ország (Irán és Izrael), valamint Törökország. A +1 állam a Palesztin Hatóság területére és önkormányzatiságára utal, amely része ugyan a Ligának, de az állami szuverenitás ismérvei jelenleg hiányoznak, így a nemzetközi jog születőfélben lévő államként (in status nascendi) hivatkozik rá. 
Állam, Núszra Front) térdre kényszerítése érdekében nyúltak katonai eszközökhöz.

\section{Az ún. Líbia-modell}

A Kaddáfi-rezsimmel való amerikai elégedetlenség az 1980-as évekre vezethetố vissza, ugyanis Líbia nemesak a nemzetközi terrorizmus támogatásában vett részt, hanem korábban már tömegpusztító (vegyi, biológiai és nukleáris) fegyverek szerzésére is lépéseket tett. A Reagan-adminisztráció éveiben meglehetősen kiéleződött Washington és Tripoli viszonya. A konfliktus eseményei közé sorolhatjuk a nyugatberlini La Belle szórakozóhely elleni 1986-os bombamerényletet és az annak megtorlására indított amerikai akciót. A konfrontáció többek között Moammar Kaddáfi gyermekének életébe került. A Kaddáfirezsim az Egyesült Államokban 1979 óta a terrorizmust támogató államok listáján szerepel, s ennek következtében tilos Líbia számára amerikai fegyvereket eladni, illetve amerikai segélyt nyújtani. 1982 ben a Reagan-adminisztráció megtiltotta a líbiai kőolaj importját is. Az események 1988-ban, a PanAm amerikai utasszállító elleni líbiai merényletben kulminálódtak; az ún. Lockerbie-incidens során 259 civil veszítette életét (Ronen, 2008, 16-40. o.).

A szakirodalom a Líbiával szembeni büntetőintézkedések alkalmazásának három szakaszát különíti el:

1. 1981 és 1988 között: katonai jellegű fellépés (főként a Reagan elnökség idején);

2. 1989 és 1998 között: inkább multilaterális szankciópolitika;

3. 1999 és 2003 között: titkos tárgyalásokra alapozott diplomáciai sikerek (Jentleson és Whytock, 2005, 47-86. o.).

Az első szakasz a szankciók céljainak a megvalósulása szempontjából kevésbé tekinthető sikeresnek, de a hidegháborús rivalizálás megszűnése a Lockerbie-incidenst követően kedvező nemzetközi kör nyezetet teremtett 1992-ben. Az Egyesült Államok és Nagy-Britannia az Egyesült Nemzetek Szervezetéhez fordult az észak-afrikai állam 


\section{Külïgyi Szemle}

nemzetközi izolációja, illetve a terrorcselekmény kapcsán lefolyta tandó büntetőeljárás végett. Az ENSZ Biztonsági Tanácsának 748-as számú határozata széles körú embargót vezetett be, amely nemcsak a termékek, hanem a személyek mozgását is korlátozta, 1993-ban pedig fegyverembargóval és a küllföldön található líbiai eszközök zárolásával is kiegészitette (Schwartz, 2007, 557. o.).

Az 1980-as években Líbiát súlyosan érintették az ún. külső gazdasági sokkok. Mindenekelőtt az olaj világpiaci árának a csökkenését szüikséges kiemelni, amely a líbiai költségvetésre eróteljesen negatív hatást gyakorolt. A szakirodalomban jelentős vita folyik arról, hogy a líbiai gazdasági válság elsődlegesen az externális gazdasági hatásoknak vagy inkább a szankcióknak a következménye-e. A két negatív körülmény felerősítette egymást. Empirikus elemzések azt igazolják, hogy az egyoldalú amerikai szankciók kevésbé voltak hatékonyak, hiszen az amerikai olajvásárlási tilalmat Líbia képes volt kiváltani, azonban az állam olajbevételei ennek ellenére az 1981-es 21 milliárd dollárról 1986-ban 5,4 milliárdra estek vissza (Nephew, 2018.).

Az 1992-93-as multilaterális szankcióknak már érezhető hatá suk volt a líbiai gazdaságra: az infláció elszabadult, az olajtermelés átlagosan évi 8 százalékkal esett, és a büntetőintézkedések az életszínvonalra is negativan hatottak (Newnham, 2010). Emellett más elemzések azt is megállapítják, hogy a líbiai olajexport számottevően csökkent ugyan, de az Európai Unió déli tagállamai továbbra is felvá sárolták az ottani szénhidrogéneket. Mindez különösen fontos a fentiekben említett elméleti kérdés kapcsán: a kereskedelem eltérítése megoldhatja bizonyos felvevő államok kiesését. Azonban az 1990-es években a líbiai olajipar hosszú távú, közvetlenüil nehezen mérhető károkat szenvedett azáltal, hogy a helyi olajmérnökök küllföldi képzését a szankciók megakadályozták, továbbá a korszerú olaj- és gázipari gépek, technológiák beszerzése is akadályokba ütközött.

1996-ban a Clinton-adminisztráció - a latorállamokkal kapcso latos, fentiekben ismertetett szigorúbb fellépése részeként - elfo gadta az ún. Irán-Líbia szankciókról szóló törvényt (The Iran-Libya Sanctions Act, ILSA), amely amerikai és nem amerikai vállalatoknak a 
líbiai és iráni olajiparba történő 20 millió dollár feletti beruházásait bünteti. A listán szereplő hét lehetséges szankcióból legalább kettőt kell alkalmazni az érintett gazdasági szervezetekkel szemben. A szakirodalom kiemeli, hogy Líbia vonatkozásában a multilaterális, illetve az Egyesüilt Államok által fenntartott szankciók rendszere hatékony volt, ugyanis az észak-afrikai állam viszonylag kis gazdasággal és a szénhidrogén termelésére és értékesítésére épülő gazdasági struktúrával rendelkezett, valamint a nyomásgyakorláshoz számos állam csatlakozott (Newnham, 2010, 2. o.).

A Kaddáfi-rezsim 1999-ben nyitásra szánta el magát, de annak az előfeltétele a Lockerbie mellett, valamint a Nigerben történt repülő gép-merénylet ${ }^{2}$ elkövetőinek a kiadása, továbbá a tömegpusztítófegyver-programmal való teljes leszámolás volt. A nemzetközi közösség - élén az Egyesült Államokkal - cserébe a szankciós rezsim feloldását ígérte Líbiának. A szakirodalomban ezen a ponton elméleti vita folyik az ún. Líbia-modell versus az ún. Ukrajna-modell alkalmazásával kapcsolatban. Ukrajna ugyanis csak azt követően szerelte le az országban található korábbi szovjet nukleáris arzenált, hogy biztonsági garanciát kapott - többek között Washingtontól - az állam területi integritásának és biztonságának a szavatolására. Líbia esetén azonban először a Kaddáfi-rezsimnek kellett a nemzetközi közösség felé vállalt kötelezettségeket teljesítenie, azt követően következhetett csak a szankciók feloldása. ${ }^{3}$ A vita tehát abban áll, hogy vajon először a tömegpusztító fegyverprogrammal rendelkező állam tegyen-e lépéseket, vagy első ként a szankciókat oldják fel. A líbiai esetben az első következett be.

2 Az UTA francia légitársaság 722-es számú járata terrortámadás következtében Ni ger felett lezuhant, a merénylet következtében 170 fő vesztette életét. A vizsgálatok során egy kongói mellett hat líbiai állampolgárt gyanúsítottak. Líbia érintettsége a vele szomszédos Csáddal 1978 óta zajló háborús konfliktus révén került főkuszba.

3 A vita küilönösen az észak-koreai nukleáris válság(ok) kezelése kapcsán merült fel. Az 1994-ben aláírt ún. genfi megállapodások részben az engedékenyebb ukrajnai példát követték, azonban a 2002-ben kezdődött ún. második válság kezelésénél a Bush-adminisztráció egyértelműen a szigorúbb líbiai út megvalósítását követelte. illetve azt szabta a tárgyalások elôfeltételeként. Észak-Korea azonban éppen az ukrajnaihoz hasonló biztonsági garancia előzetes biztosítását követelte az Egye sült Államoktól (V.ö. Hecker, 2010). 


\section{Külïgyi Szemle}

Líbia és a nemzetközi közösség viszonyában 1999-ben indult el a változás. Áprilisban Tripoli kiadta a Lockerbie-incidens két feltételezett elkövetőjét, majd titkos tárgyalásokat kezdett például az Egyesült Államokkal. Egyes vélemények szerint a 2001. szeptember 11-i terrortámadás kifejezetten javított a Kaddáfi-rezsim nemzetközi helyzetén, amennyiben a terrorizmusellenes háborúban a Washingtonnal való együttmúködést helyezte elôtérbe. Kaddáfi elismerte Líbiának a Lockerbie-merényletben való érintettségét, elítélte a terrorizmus valamennyi formáját, továbbá a líbiai állam megkezdte a 259 halálos áldozat családjának az anyagi kártérítését is. Emellett pedig végérvényesen lemondott minden tömegpusztítófegyver-programjáról is. 2003 szeptemberében az ENSZ BT 1506-os számú határozata feloldotta a szankciókat, majd az USA részéról a kétoldalú kapcsolatokban is fokozatos normalizáció következett be: Líbiát 2006-ban vették le a terrorizmust támogató országok listájáról (Newnham, 2010, 15-17. o.).

A szakirodalomban jelentős vita folyik arról, hogy a Bush elnök által indított globális terrorizmusellenes háborúnak (különösen a 2003 as iraki beavatkozásnak) mennyiben volt/van elrettentő ereje az ún. latorállamok szempontjából. Líbiának a nemzetközi közösséggel való együittműködése mennyiben vezethető vissza az ország belső problémáira (amelyek egy része összefügg a szankciós rezsimmel), és menynyiben a külsô nyomás hatása? Líbia esetét a tudományos elemzések általában olyan példaként használják, ahol a 2003-as iraki beavatkozás elrettentő ereje megfelelően mûködött (St John, 2004, 394-395. o.). Líbiában - legalábbis a 2011-es összeomlásig - elkerülhetô volt a nemzetközi beavatkozás, és a szankciók feloldását követően a gazdaság látványosan növekedő pályára állt. A jelen tanulmány a 2011es „arab tavasz” eseményeinek a bemutatására terjedelmi okok miatt nem tér ki. Az iráni szankciókkal kapcsolatosan szüikséges fontos történelmi referenciákról a fentiekben pedig már szó volt. 


\section{Szudán}

Szudán az 1989-es katonai puces eredményeként kialakult iszlamista rezsim miatt került a nemzetközi figyelem középpontjába. Az országot 1989 és 2019 között, azaz három évtizeden át uraló Omar Haszan Ahmed al-Basír tábornok két érzékeny ügyben is kiváltotta az Egyesült Államok rosszallását. Az egyik, hogy a Basír-rezsim a belpolitikában a meglehetősen népszerútlen félkatonai erőket, az ún. Dzsandzsavíd milíciákat ${ }^{+}$használta fel - többek között - az erószakos arabizációs politikája megvalósítása érdekében. Az országban folyó harcok közül az Észak- és Dél-Szudán közti polgárháború mellett szüikséges megemlíteni az ún. dárfúri felkelést is, amely különösen 2004-ben, a ruandai népirtás tizedik évfordulóján vált súlyossá. A Basír-rezsim az említett paramilitáris eróket alkalmazta, amikor Dárfúrban katonailag beavatkozott, és a nem arab törzsekkel szemben fellépett. Egyes emberi jogi szervezetek népirtásnak nevezték az akkori eseményeket, és a nemzetközi közösség fellépését szorgalmazták. A nemzetközi jogászok nagyobb része szerint azonban az ott történtek nem merítették ki a népirtás fogalmát.

A másik ügy, ami az USA nemtetszését vonta maga után, hogy a Basír-rezsim az 1990-es években - Líbiához hasonlóan - a nemzetközi terrorizmus támogatásának útjára lépett. 1992 és 1996 között az akkori globális dzsihadista szervezet, az al-Káida tevékenységének a túlnyomó része Szudánból indult ki. Például az amerikai katonákat Szomáliában ért 1993-as támadás, valamint a Hoszni Mubárak egyiptomi elnök elleni 1995-ös etiópiai merényletkísérlet is az al-Káida számlájára írható. A kenyai, illetve a tanzániai fơvárosban lévő amerikai követséget 1997 augusztusában ért támadás mögött úgyszintén a terrorszervezet állt. A Basír-rezsim a támogatásáról biztosította az al-Káida Szudánba érkező vezetőit, de a szervezet 1996-ban, bár tovább folytatta a tevékenységét a nílusi államban is, a bázisát a tálib

4 Jelentése: lovon ülő ember. A Dzsandzsavíd tagjai gyakran a kormány katonai egyenruhájában jelentek meg, és többnyire az általa biztosított fegyvereket és terepjárókat használták az atrocitások során. Több alkalommal is nőket erőszakoltak meg, a tiszta ivóvizet beszennyezték, és a helyiek életét ellehetetlenítették. 


\section{Külïgyi Szemle}

mozgalom által dominált Afganisztánba helyezte át (Cockett, 2010, 143-210. о.).

Az Egyesült Államok és Szudán viszonya a hidegháborús évtize dekben sem volt pozitívnak mondható, ugyanakkor az 1990-es években a szankciók fokozatos bevezetésére is sor került. Szudán 1993-ban került fel a terrorizmust támogató országok listájára, ami önmagában is az egyoldalú szankciók egyik formájának tekinthető. ${ }^{5}$ Washington korlátozta továbbá a kétoldalú kereskedelmi forgalmat, leállította a védelmi eszközök értékesítését, illetve az adósság visszafizetése kap csán nem engedélyezett könnyítést. Ezzel együtt 1988 és 2001 között évente átlagosan 48 millió dollárnyi élelmiszersegélyt juttatott az országnak - de ez töredéke volt a korábbi támogatásnak (Rennack, 2005, 6. o.). Az Egyesült Államok 1996-ban bezárta a kartúmi követ ségét, 1997-ben pedig egy olyan gyógyszergyár ellen indított bom batámadást, amely a feltételezések szerint az al-Káida militáns te vékenységéhez volt köthető. Végül a Clinton-adminisztráció - amely a líbiai szankciós rezsimet is megszigorította - 1997 novemberében egy elnöki rendelettel kereskedelmi embargót vezetett be a Basír rezsimmel szemben (Malik és Malik, 2015, 3. o.).

Az Egyesült Államok megpróbálkozott egy, a Basír-rezsim elleni ko alíció kialakításával, azonban a nemzetközi fórumokon, így különösen az Egyesuilt Nemzetek Szervezetében, csak korlátozott multilaterális szankciók bevezetését sikerült elérnie, ugyanis a Kínai Népköztársaság (és többnyire Oroszország) nem támogatta a szélesebb körú fellépést. A 2004-es dárfúri incidens azonban a rezsim nemzetközi megítélésének a további romlásához vezetett. Az ENSZ BT 1556. határozata - Kína és Pakisztán tartózkodása mellett - teljes körủ fegyverembargót írt elő, valamint követelte a kartúmi kormánytól a Dzsandzsavíd milíciák lefegyverzését. 2005 márciusában a BT 1591-es határozata - három ország, köztük Kína tartózkodása mellett - a dárfúri békefolyamatot megakadályozó szereplők vagyonának a befagyasztását és a külföldi utazásuk tilalmát rendelte el, valamint a tagállamokat további

5 Jelenleg a terrorizmust támogató államok listáján az alábbi országok szerepelnek: Szíria, Irán, Észak-Korea és Kuba (Congressional Research Service, 2021). 
szankciós intézkedésekre szólította fel. A 2006-ban elfogadott 1672. határozat négy szudánival szemben hozott büntetőintézkedéseket Kína ismételt tartózkodása mellett. A nemzetközi aktorok közül az Európai Unió hasonlóképpen cselekedett, mint az Egyesült Államok, így már 1994-ben fegyverembargót léptetett életbe Szudánnal szemben (Kreutz, 2005, 32. о.).

A 2004-es, majd az azt követő dárfúri atrocitások a Nemzetközi Büntetőbíróság (International Criminal Court, ICC) figyelmét is felkeltették, így 2008-ban a szervezet föügyésze emberiesség elleni búncselekménnyel, népirtással és háborús bűnökkel vádolta meg Basírt, majd 2009-ben nemzetközi elfogatóparancsot adott ki ellene. Mivel Szudán nem részese a római statútumnak, így az ENSZ Biztonsági Tanácsának 1593-as számú határozata utalta a dárfúri ügyet az ICC elé, amely együttmúködésre kötelezte a kartúmi kormányzatot. A határozat kapcsán négy állam (az Egyesült Államok, Kína, Algéria és Brazília) is a tartózkodását fejezte ki. Kartúm az elfogatóparancsra a segélyszervezetekkel szembeni fellépéssel, tagjaik kiutasításával válaszolt (Duursma és Müller, 2019, 890-907. o.). Basír közben több ízben is küllföldre utazott, az elfogását mégsem sikerüilt végrehajtani.

Érdemes ehelyütt arra is kitérni, hogy a kartúmi kormányzat ál talában kettős politikát folytatott a nemzetközi közösséggel való kap csolataiban. Annak jelentősebb nyomásgyakorlása esetén ugyanis együttmúködést színlelt. Például 1996-ban szudáni politikusok titkos tárgyalásokat folytattak Washingtonban Oszáma bin Láden esetleges kiadásáról. Talán a leglátványosabban az ún. szudáni békefolyamat során mûködtek együtt, amely az IGAD_tárgyalások során bontakozott ki, s az északi és a déli országrész között 1983 óta dúló polgárháborús helyzetből kínált kiutat. Az IGAD béketerve - az utóbbi térség, azaz a kartúmi rezsim számára hátrányosan - az önrendelkezési jog megadását javasolta. 2005 januárjában végüil a Basír-rezsim és a déli felkelőket reprezentáló Szudáni Népi Felszabadítási Mozgalom/Hadsereg (Sudan's People Liberation Movement/Army, SPLM/A)

6 Intergovernmental Authority on Development, regionális szervezet, amely nyolc államot tömörít. 


\section{Külïgyi Szemle}

szervezet aláírta az ún. átfogó békemegállapodást (Comprehensive Peace Agreement, CPA), amely egy, a hatalommegosztásról szóló 5,5 éves átmeneti időszakot jelölt ki. A kartúmi kormányzat együtt működése lehetővé tette, hogy 2011 júliusában Dél-Szudán éljen az önrendelkezési joga gyakorlásával, és elszakadjon Szudántól. Ehelyütt terjedelmi okok miatt nincs lehetôség részletezni az eseményeket, de valószínúsíthető, hogy a rezsim a saját életben maradása és nemzetközi megítélésének a javitása érdekében dönthetett a Washington által támogatott békefolyamatban való részvételrỏl.

A fenti folyamatokból látható, hogy - a líbiai esettől eltérően a nemzetközi közösség részéről nem volt egyetértés a multilaterális szankciók szudáni alkalmazása kapesán, az országot sújtó büntetőintézkedések többnyire egy-egy nagyhatalmi szereplő (USA, EU) egyéni döntésein múltak. Szudánban a nemzetközi beavatkozás veszélye kevésbé fenyegette a rezsimet, az ICC által kiadott elfogatóparancs pedig éppen nem az együttmúködésre késztette a rezsimet.

2019-ben az „arab tavasz” ún. második hulláma hirtelen véget ve tett a rezsimnek, és az utána kijelölt 39 hónapos politikai átmenet lezárulta 2024-ben várható. Az Obama-adminisztráció azonban még 2017 januárjában megfogalmazta az országgal szembeni szankciók feloldását, amelynek a végrehajtása csak a Trump-éra alatt történt meg, 2017 novemberében. Az Egyesült Államok öt területen (five track) írt elő haladást Szudán számára (pl. a dél-szudáni polgárhá ború eseményeibe való be nem avatkozás, a dárfúri katonai cselekmények beszüntetése stb.), amelyeket Washington szerint a kartúmi kormányzat jól teljesített. Mindezek ellenére Szudán a terrorizmust támogató államok listáján maradt (Verjee, 2018). A törlés feltétele az Izraelhez fủződő kapcsolatoknak az Ábrahám-megállapodások kere tében történő normalizálása volt. A 2019-ben beiktatott Szuverenitási Tanács vezetője, Abdel-Fattáh Abdel-Rahmán Burhán diplomáciai egyeztetéseket kezdett Mike Pompeo amerikai külïigyminiszterrel, amelyek eredményeként 2020. október 23-án Kartúm hivatalosan normalizálta a viszonyát a Netanyahu-kormánnyal. 2020 decemberében így Szudán lekerült a listáról (Ramani, 2021). 
A kérdés, ami felmerül, alapvetően az, hogy mennyiben a rezsimváltás volt az előfeltétele annak, hogy Szudán és az Egyesült Államok viszonyában pozitív áttörés következzen be. Ebből a szempontból an nak ellenére sem lehet figyelmen kívül hagyni az ICC tevékenységét, hogy az Egyesüllt Államok nem részese az azt létrehozó római statútumnak. Mennyiben vonatkoztatható ugyanez a kérdés Szíriára, illetve Iránra, ahol a rezsimváltás érdekében kezdeményezett katonai beavatkozásra kevésbé számíthatunk?

\section{Szíria}

Mint ismeretes, Szíriában a 2011-ben elindult tüntetési hullám a következô évben polgárháborúvá alakult. Az erőszakos események során a nemzetközi közösség részéről megosztottság mutatkozott abban a kérdésben, hogy az országot 2000 óta irányító Bassár alAszad mennyiben tekinthető legitim vezetőnek, és támogatható-e a hatalom élén maradása. Az Aszad-rezsim 2018-2019-ben, az Iszlám Állam legyőzésével párhuzamosan, katonai szempontból megerősödött, a politikai folyamatokra pedig leginkább három külső aktor, az ún. asztanai folyamatban részt vevő Oroszország, Törökország és Irán nyomja rá a bélyegét. A Szíria kapesán kibontakozott nemzetközi vita során az Európai Unió és az Egyesült Államok az ENSZ BT 2005-ben elfogadott 2254-es határozatára építi az érveit, amely egy politikai átmenetet jelölt ki az ország számára. Az EU és az USA értelmezése szerint Bassár al-Aszadnak távoznia kell a hatalomból.

Az Amerikai Egyesült Államok már 1979-ben felhelyezte Szíriát a terrorizmust támogató államok listájára, a 2000-es években pedig tovább bővítették az ellene hozott szankciók körét: fegyverembargót léptettek életbe, leállították az amerikai kormányzati támogatást, valamint megtiltották egyes szíriai állampolgároknak az Egyesüilt Ál lamok területére való belépését. A szélesebb szankciós rezsim be vezetése a 2003-as ún. Szíria elszámoltathatósági törvényhez (Syria Accountability Act) és a Bush-adminisztráció időszakához köthető, amely jelentős mértékben szigorított a korábbi büntetőintézkedéseken. 


\section{Külïgyi Szemle}

Az „arab tavasz” 2011-ben további szigorítást, s végső soron az Egye sült Államok és Szíria közti kereskedelmi kapcsolat teljes leállását vonta maga után (The Carter Center, 2020).

2019-ben, a Trump-adminisztráció időszaka alatt, Washington másodlagos szankciókat ${ }^{7}$ vetett ki az ún. Ceasar-törvény értelmében, amelynek elsődleges célja a civilek védelme. A másodlagos szankciók olyan államokat, vállalatokat vagy személyeket sújtanak, amelyek/ akik bizonyos területen együttműködnek az Aszad-rezsimmel. A feloldásukhoz a törvény szerint hat olyan feltételnek kell teljesülnie, amelyeknek együttesen a kimondottan a civilekkel szemben elköve tett - kormányzati, orosz és iráni - katonai hadmúveleteknek a végét kell jelenteniüik. Az Európai Unió 2011-ben vezetett be célzottabb és kevésbé általános szankciókat. Például nem a teljes kereskedelmi kapcsolatot állította le, hanem bizonyos területekre vonatkozóan korlátozza azt. Emellett fegyverembargót, a szíriai kormánytagokkal és egyes üzletemberekkel szemben utazási tilalmat és egyéb szankciókat vezetett be, valamint a befektetéseket korlátozta.

Az Egyesült Államok és az Európai Unió által külön-küiön életbe léptetett szankciók végső soron azzal járnak, hogy a nyugati világ jelenleg nem támogatja anyagilag a szíriai újjáépítést. Felmerüil a kérdés itt is, hogy mennyiben van Aszad távozásához kötve a szankciók feloldása. Az amerikai szankciók minden bizonnyal szerepet játszottak a szíriai font 2020-as összeomlásában. Egy tanulmány viszont azt állítja, hogy az a már a Ceasar-szankciók kivetése előtt is meglévő gazdasági problémákra vezethető vissza, a másodlagos szankciók inkább még jobban felerősítették az amúgy is létezô gondokat (Center for Operational Analysis and Research, 2020). A gazdasági összeomlás azonban nem akadályozta meg, hogy Bassár al-Aszadot 2021 júliusában 95 százalékos többséggel újra elnökké válasszák - a voksolás demokratikus jellegével szemben több ellenérv is felhozható. Összességében kijelenthető, hogy az elsődleges és a másodlagos szankciók érezhető problémákat okoztak Szíriának, azonban a céljukat nem érték el.

7 A másodlagos szankciók kapcsán lásd Ruys és Ryngaert, 2020, 1-16. o. 


\section{I rán}

\section{Mennyiben ellenálló a rezsim és a gazdaság?}

Irán az 1979-es iszlám forradalom óta az Egyesült Államok által pá riaállamnak tekintett közel-keleti szereplő. Az ellene alkalmazott komplex szankciós rendszer bilaterális és multilaterális megközelítés re épüil, és a motivációját tekintve két elküiöníthető időszakra osztható fel: míg Washingtonnak az 1979 és 2002 között Iránnal szemben hozott intézkedései elsősorban a perzsa állam regionális pozícióját kísérelték meg marginalizálni, addig a 2002-ben bevezetettek főként az iráni nukleáris program kapesán bontakoztak ki. ${ }^{8}$

1979-ben, különösen a teheráni túszdráma következményeként, a Carter-adminisztráció szankciókat vetett ki Iránra (pl. kereskedelem beszüntetése, az Egyesült Államokban található iráni vagyon teljes befagyasztása), valamint 1980-ban felfüggesztette a diplomáciai kapcsolatokat. 1981-ben, miután az amerikai diplomaták kiszabadultak, az USA feloldotta a kereskedelemre vonatkozó korlátozások egy részét. A tanulmánynak nem célja az amerikai-iráni kapcsolatok teljes körű áttekintése, pusztán az elmúlt évek szankciós politikájának a hatásaira kíván rámutatni.

Az amerikai-iráni relációban a Clinton-adminisztráció által az 1990-es években doktrínaszintre emelt ún. kettős feltartóztatás politikája (dual containment policy) emelhető ki, amelynek keretében Washington az Irak és Irán közötti egyensúly fenntartására törekedett, hogy egyik se erősödjön meg a másik kárára. Ezzel összefüiggésben vezették be a korábban említett Irán-Líbia szankciókról szóló tör vényt, ${ }^{9}$ amely korlátozta a két közel-keleti állammal való kereskedelmi forgalmat. Valójában Bill Clinton már 1995-ben kiadta azt az elnöki rendeletet, amely megtiltja a perzsa állammal való kereskedelmi kap csolatokat, illetve a befektetéseket - továbbá az olajvásárlást is.

8 Az Egyesült Államok által Iránra kivetett szankciókról lásd részletesen: Katzmann, 2019.

9 A késóbbiekben Iran Sanctions Actre változott a neve, miután a Líbiával kapcso latos szankciókat feloldották. 


\section{Külïgyi Szemle}

A szankciós politika második szakasza 2002 után vette kezdetét, s a hátterében a 2001. szeptember 11-i terrortámadás és az annak következményeként megindított terrorizmusellenes háború állt. Mint ismeretes, Bush elnök 2002. januári, a kongresszus előtt tartott beszédében a „gonosz tengelyéhez” sorolta Irán, Irakot és Észak-Koreát, azzal vádolva a három országot, hogy a terrorizmust támogatják, illetve tömegpusztító fegyverek gyártására, szerzésére törekednek. Még ugyanabban az évben egy iráni ellenzéki csoport bejelentette, hogy az ország titkos nukleáris programot folytat - és ezzel kezdetét vette a mai napig tartó ún. iráni nukleáris válság (N. Rózsa, 2008, 19-27. o.).

Az iráni vezetés 2002 és 2005 között együttmúködött a Nemzetközi Atomenergia-ügynökséggel, azonban a 2005-ös elnökválasztás nyertese, Mahmúd Ahmadinezsád keményebb hangvételre váltott, és az addigi ún. P5+1-tárgyalások is megszakadtak. A nukleáris program (lásd N. Rózsa, 2021) következtében kivetett bilaterális és multilaterális szankciókat elsősorban 2005-tól érvényesítették. Az Európai Unió 2007 áprilisában foganatosította a szankciók első körét Iránnal szemben, amely elsődlegesen a nukleáris ipart érintette, valamint személyekre és vállalatokra is korlátozásokat vezetett be. Ezt követően fokozatosan szigorította - a nemzetközi szerepvállalással összhangban - a büntetőintézkedéseket, amelyek közül a 2012-es olajembargó emelhető ki. Mindezek hatására 2013-ra az iráni-európai uniós kereskedelmi kapcsolatok drasztikusan visszaestek, az EU iráni exportja hétmilliárd euróra, az importja egymilliárd euróra esett vissza (Ghodsi és Karamelikli, 2020, 2. o.). Az Egyesült Államok ugyancsak 2013-ban szigorított az Iran Sanctions Acten (a továbbiakban: ISA), és más államok is életbe léptettek szankciókat - többek között Ausztrália és Kanada is -, amelyek bemutatására a jelen tanulmányban nincs hely.

A bilaterális szankciók mellett az ENSZ Biztonsági Tanácsában is elindult a vita az iráni nukleáris kérdésról, az évente elfogadott szankciók köre egyre szélesebb, amit az 1. táblázat részletez. 
1. táblázat

Az iráni nukleáris program kapesán kivetett fontosabb ENSZ-szankciók áttekintése

\begin{tabular}{|c|c|c|c|}
\hline $\begin{array}{l}\text { ENSZ BT- } \\
\text { határozat } \\
\text { száma }\end{array}$ & $\begin{array}{c}\text { A határozat } \\
\text { dátuma }\end{array}$ & A határozat tartalma & $\begin{array}{l}\text { A szavazás } \\
\text { eredménye }\end{array}$ \\
\hline 1737 & $\begin{array}{c}2006 . \\
\text { december } 23 .\end{array}$ & $\begin{array}{c}\text { nukleáris technológiák és } \\
\text { alapanyagok értékesítésének tilalma, } \\
\text { a nukleáris programmal kapcsolatba } \\
\text { hozható vállalatokkal és } \\
\text { személyekkel szembeni lépések }\end{array}$ & $\begin{array}{l}\text { egyhangú } \\
\text { támogatás }\end{array}$ \\
\hline 1747 & $\begin{array}{c}2007 . \\
\text { március } 24 .\end{array}$ & $\begin{array}{c}\text { fegyverembargó bevezetése, } \\
\text { további intézkedések a nukleáris } \\
\text { technológia és eszközök } \\
\text { befagyasztása terén }\end{array}$ & $\begin{array}{l}\text { egyhangú } \\
\text { támogatás }\end{array}$ \\
\hline 1803 & $\begin{array}{c}2008 . \\
\text { március } 3 .\end{array}$ & $\begin{array}{c}\text { az urándúsítás és a } \\
\text { centrifugafejlesztések leállításának } \\
\text { követelése }\end{array}$ & $\begin{array}{l}\text { indonéz } \\
\text { tartózkodás } \\
\text { mellett } 14 \\
\text { támogatás }\end{array}$ \\
\hline 1929 & $\begin{array}{c}2010 . \\
\text { június } 9 .\end{array}$ & $\begin{array}{l}\text { annak megállapítása, } \\
\text { hogy Irán nem múködik együtt } \\
\text { a nukleáris program kapcsán, } \\
\text { és további szankciók életbe léptetése }\end{array}$ & $\begin{array}{c}\text { Brazília és } \\
\text { Törökország } \\
\text { ellenszavazata, } \\
\text { Libanon } \\
\text { tartózkodása, } \\
13 \text { támogatás }\end{array}$ \\
\hline 2231 & $\begin{array}{c}2015 . \\
\text { július } 20 .\end{array}$ & $\begin{array}{c}\text { a nukleáris megállapodás (JCPOA) } \\
\text { jóváhagyása }\end{array}$ & $\begin{array}{l}\text { egyhangú } \\
\text { támogatás }\end{array}$ \\
\hline
\end{tabular}

A legfontosabb ENSZ BT-szankciókat összefoglaló táblázatból jól látszik, hogy miközben egyes államok - mint Oroszország és Kína széles körű politikai és gazdasági kapcsolatokat ápolnak Iránnal, mégis támogatják a szankciókat, illetve azok szigorítását. A 2010. júniusi 1929-es számú ENSZ BT-határozatot két nem állandó tag, Törökország és Brazília nem támogatta. Ennek hátterében az a török-brazil kezdeményezés áll, amelynek keretében a két állam 2010 tavaszán diplomáciailag kísérelte megoldani a vitát: azzal a javaslattal álltak elő, hogy az iráni uránkészlet felét Törökországba szállítsák dúsításra, majd annak egy részét juttassák vissza Iránba orvosi felhasználásra. 


\section{Külïgyi Szemle}

A szankciók hatására az „ellenállás frontját” vezető Iránban a leg fơbb vezető 2014-ben hirdette meg az ún. „ellenálló gazdaság” dokt rínáját (economic resistance doctrine), amelynek célja, hogy a perzsa állam gazdasági prosperitását függetlenné tegye a büntetőintézkedésektől, illetve egyéb, a globális gazdaság okozta sokkoktól (N. Rózsa és Szigetvári, 2019, 169-182. o.). A rezisztens gazdaság koncepció ja szorosan kapcsolódik az iráni védelmi és külpolitikához, vagyis a nemzetbiztonság része. 2011 júliusában napi közel 3 millió hordó volt az olajtermelés mértéke, ami 2012 közepére - részben az EU által bevezetett olajembargó következtében - napi 1 millió hordó alá esett. Mindez azt mutatja, hogy abban az évben az iráni gazdaság nem volt képes kivédeni a kívüilről érkező sokkokat (Toumaj, 2014).

\section{2. táblázat ${ }^{10}$}

A főbb ázsiai államokba irányuló iráni olajexport 2011 és 2016 között (hordó/nap)

\begin{tabular}{|c|c|c|c|c|}
\hline Év & Kína & India & Dél-Korea & Japán \\
\hline 2011 & 555.000 & 320.000 & 250.000 & 315.000 \\
\hline 2012 & 438.358 & 315.733 & 154.683 & 186.592 \\
\hline 2013 & 429.717 & 196.367 & 134.133 & 185.400 \\
\hline 2014 & 549.675 & 276.083 & 124.842 & 169.358 \\
\hline 2015 & 532.708 & 207.625 & 116.533 & 170.467 \\
\hline 2016 & 552.025 & 321.375 & 248.100 & 191.760 \\
\hline
\end{tabular}

A fokozódó nemzetközi nyomásnak elsősorban az iráni riál árfolyamában, az olajexportban és végső soron a gazdasági növekedés adataiban van tetten érhető következménye. Az iráni gazdaság (lásd: Fórián-Szabó és Kovács, 2021) 2012-ben 7,7 százalékkal esett vissza az előző évhez képest, a riál pedig 2011 és 2012 között jelentős mér tékben vesztett az értékéből. A kieső olajexport egy kisebb hányadát Kína és más ázsiai gazdaságok szívták fel. Ez is azt bizonyítja, hogy a szankcióknak - ahogy arról az elméleti részben szó volt - kereskede lemelterelő hatásuk van. Az embargó a gyakorlatban annyit jelentett,

10 Forrás: Middle East Institute, 2016. 
hogy más útvonalakon keresztül, tulajdonképpen drágábban jutottak el a termékek Iránba. Továbbá a riál értékvesztése miatt a középosztály körében felértékelődtek az olyan termékek, mint az értéktartó luxusórák." Az átutalások tekintetében pedig Törökország és az Egyesült Arab Emirátusok közvetítő államként betöltött szerepe emelhető ki.

\section{3. táblázat ${ }^{12}$}

Irán gazdasági növekedése 2011 és 2020 között

\begin{tabular}{|c|c|}
\hline $\mathbf{E} v$ & $\begin{array}{c}\text { a GDP volumenének változása } \\
\text { az elözó évhez képest (százalék) }\end{array}$ \\
\hline 2011 & 2,6 \\
\hline 2012 & $-7,5$ \\
\hline 2013 & $-0,2$ \\
\hline 2014 & 4,6 \\
\hline 2015 & $-1,3$ \\
\hline 2016 & 13,4 \\
\hline 2017 & 3,8 \\
\hline 2018 & $-6,0$ \\
\hline 2019 & $-6,8$ \\
\hline 2020 & 1,7 \\
\hline
\end{tabular}

A 3. táblázatból jól látszik, hogy a szankciók szigorításának a hatása megmutatkozik a GDP éves változásában is, és a kieső olajexport 2012-ben jelentős gazdasági visszaesést okozott. Az iráni gazdaságról szóló elemzések azonban rendre megállapítják, hogy az komoly strukturális problémákkal küzd, a problémái önmagukban nem vezethetők vissza a nemzetközi büntetőintézkedésekre, a szankciók valójában felerősítették a meglévő nehézségeket (Habibi, 2018).

11 Személyes interjúk Teheránban, 2016-ban és 2018-ban.

12 Forrás: The World Bank, 2021. 


\section{Külïgyi Szemle}

\section{A 2015-ös nukleáris megállapodás és annak összeomlása}

2015 júliusában az P5+1 (az ENSZ BT öt állandó tagjai - az Ame rikai Egyesüllt Államok, az Egyesüllt Királyság, Franciaország, Kína és Oroszország -, valamint Németország) aláirta az iráni nukleáris megállapodást (Joint Comprehensive Plan of Action, Közös Átfogó Cselekvési Terv, JCPOA), amelynek értelmében a közel-keleti ország nukleáris programja kapesán megfogalmazott korlátozások betartása fejében a bi- és multilaterális szankciós rendszer fokozatos feloldását igérték az iráni vezetésnek. A folyamat fontos előzménye, hogy a 2013 ban hatalomra került iráni elnök, Haszan Roháni békülékeny hangot ütött meg, és tárgyalásokat kezdeményezett a nagyhatalmakkal az iráni nukleáris programmal kapcsolatosan. Mint ismeretes, Iránban a legfontosabb külpolitikai döntéseket nem az elnök, hanem a legfóbb vezető, Ali Khamenei ajatollah hozza meg. Felmerül a kérdés, hogy az egyre szigorodó szankciók mennyiben játszottak szerepet Roháni döntésében, amely végsỏ soron összekapesolódott a centrista elnök és körei megerősödésében. A nukleáris megállapodással kapcsolatban nemcsak a nemzetközi közösség, hanem az iráni társadalom részéról is óriási várakozások fogalmazódtak meg. Roháni a beiktatásakor kifejezte, hogy a hazája gazdasági problémái nem kizárólag a szankciókra, inkább a nem megfelelő gazdasági irányításra vezethetők viszsza - ezzel egyértelmủen a 2013 előtti időszaktól és személy szerint Ahmadinezsád korábbi elnöktől kívánt eltávolodni (Coles, 2013).

Roháninak az első elnöki ciklusa (2013-2017) alatt jelentős gazdasági stabilizációt sikerült végrehajtania, amelynek eredményeként megszilárdult a riál árfolyama, egyszámjegyủ lett az infláció, és nem utolsósorban elindult a gazdasági növekedés. Mindebben jelentős szerepet játszott a szankciók fokozatos feloldása: 2016. január 16án, az „implementáció napján” ugyanis a nemzetközi ellenőrök arra a megállapításra jutottak, hogy Irán eleget tett a JCPOA-ban vállalt kötelezettségeinek, így megkezdődhetett az olaj- és a pénzüigyi szektort érintő megszorítások enyhítése, valamint 100 milliárd dollárnyi befagyasztott vagyont szabadítottak fel. 
A nukleáris megállapodás aláírásának a következményei jól lát szódnak a gazdasági növekedési adatokban. Érdemes azonban megjegyezni, hogy a szankciók feloldásának rövid távon elsősorban az olajszektorban volt érezhető a hatása - a gazdasági helyzet javulása főként az olajtermelés hirtelen emelkedéséből adódott, ám kevésbé segített úrrá lenni a gazdaság mélyebben húzódó strukturális problémáin (The World Bank, 2017). Fontos megemlíteni, hogy az Iránnal szemben alkalmazott szankciók rendszere összetett volt, így azokat nem is lehetett 2016-ban teljesen feloldani, hanem csak részlegesen. A JCPOA nem érintett két olyan kérdéskört, amelyek kulcsfontosságúak mind Washington, mind Brüisszel szemszögéből: Irán tovább folytatta a ballisztikus rakéták fejlesztését és tesztelését, továbbá az ország regionális - különösen az iraki és a szíriai - tevékenysége, expanziója ellentétes maradt a nyugati államok érdekeivel. 2016 de cemberében az Egyesült Államok Kongresszusa tíz esztendőre meghosszabbította az iráni szankciós törvényt. A szankciók feloldása és azzal párhuzamosan a meghosszabbítása ellentmondásnak tűnhet, azonban az ISA pusztán a szankciók jogi keretének tekinthető.

Donald Trump amerikai elnök 2018 májusában jelentette be, hogy hazáját augusztusban „kilépteti” a nukleáris megállapodásból, a szankciókat fokozatosan visszaállítják, sőt újabb korlátozásokat is bevezetnek a perzsa állammal szemben. Az amerikai elnök szerint ugyanis a JCPOA nem szolgálta sem gazdaságilag, sem politikailag az Egyesült Államok érdekeit. Trump meghirdette a maximális nyomás politikáját (maximum pressure policy), amelyre az iráni rezsim a maximális ellenállás (maximum resistance) stratégiájával válaszolt (Mousavian, 2021). Az amerikai diplomácia szerint a fó cél, hogy Irán „egyetlen csepp” olajat se tudjon exportálni, azaz tulajdonképpen az iráni gazdaság és azzal párhuzamosan az iszlamista rezsim térdre kényszerítése. A nukleáris megállapodást tető alá hozó P5+1 hatalom közül egyedül az Egyesült Államok „lépett ki”³ abból, az Európai Unió, Oroszország és Kína, s végsổ soron az iráni rezsim is annak a fenntartása mellett állt ki.

13 A kifejezés arra utal, hogy a JCPOA nemzetközi jogi státusa kapcsán viták vannak arról, hogy az mennyiben tekinthető nemzetközi szerződésnek (lásd: Toubman, 2021). 


\section{Külïgyi Szemle}

Washington 2018-tól fokozatosan másodlagos szankciókat lépte tett életbe azon államokkal szemben, amelyek együttmúködtek Iránnal. Washington 90 és 180 napos „türelmi időt” engedélyezett, valamint bizonyos államokkal kivételt tett az iráni olajimport kapcsán. 2019 májusától azonban már a szankciós törvény értelmében büntetőintézkedéseket hozott harmadik államok Iránnal kereskedô vállalataival szemben (Sultoon és Walker, 2019, 4-5. o.). A másodlagos szankciók bevezetése jelentős vitákat váltott ki a transzatlanti kapcsolatokban, ugyanis Brüsszel mindenáron szerette volna fenntartani a nukleáris megállapodást. Az Európai Unió 2019 januárjában INSTEX néven egy olyan pénzügyi eszközt hozott létre, amely a kétoldalú kereskedelmi kapcsolatok folytatását szolgálja. Jelenleg elsősorban a humanitárius célú együttmúködésre terjed ki - amely mellesleg nem is esik az amerikai szankciós rezsim alá (Erästö, 2020). Az INSTEX a valóságban nem váltotta be a hozzáfúzött reményeket.1+

Politikai értelemben a JCPOA kudarcot vallott. Az Egyesült Álla mok és Irán között 2019-ben és 2020-ban egy eszkalációs folyamat nak lehettünk a szemtanúi. Teherán a regionális tevékenysége foko zásával, valamint a nukleáris programot érintő JCPOA-korlátozások megszegésével válaszolt a másodlagos szankciók bevezetésére. Washington erre katonai beavatkozást hajtott végre (2020 januárjában, a bagdadi repülőtér mellett), valamint további szankciókat léptetett életbe. Ezek közé tartozott, hogy 2019-ben a külföldi terrorista szervezetek listájára helyezte az Iszlám Forradalmi Gárdát, valamint 18 iráni bankkal szemben hozott intézkedéseket, és Trump egy elnöki rendelettel az iráni nukleáris, ballisztikusrakéta-, illetve hagyományos fegyverkezési program megállitására adott utasítást.

A JCPOA értelmében 2020 októberében lejárt az ENSZ BT által kivetett (1747. számú) fegyverembargó. Az Egyesüllt Államok ezt vitatta, ugyanis a Fehér Ház álláspontja szerint Irán folyamatosan megsértette a megállapodás rendelkezéseit. Iráni olvasatban viszont

14 Ebben több tényező is szerepet játszott. Például a jelentős külkereskedelmi deficit, ugyanis az EU lényegesen többet exportál Iránba, mint amennyit importál. Így az elszámolásnak vannak bizonyos akadályai. A deficit mögött az olajimport leállása húzódik meg. 
a korlátozások figyelmen kívül hagyása a válasz Washington szerződésszegő magatartására. Teherán politikai gyơzzelemként értékelte a fegyverembargó végét, a nagyobb üzletek azonban éppen politikai okok miatt elmaradtak.

Joe Biden, akinek adminisztrációja 2021 elején lépett hivatalba, jelezte, hogy újra kívánja tárgyalni a nukleáris megállapodást és vele egyuitt a szankciókat. Áprilisban el is indultak Bécsben a titkos tárgyalások, azonban a nyáron tartott iráni elnökválasztás némiképp elnapolta a folyamatot. A 2020-ban, már a Covid-pandémia árnyékában, igen alacsony részvételi arány mellett (42,57\%) megtartott parlamenti válasz tásokon a keményvonalasok győztek. A 2021. júniusi elnökválasztáson pedig Ibráhim Ráiszi, az ún. principalisták táborához sorolható jelölt győzedelmeskedett. Érdekes kérdés, hogy az amerikai hozzáállás menynyiben felelős a keményvonalas iráni politikai körök megerősödésében.

Fontos kitérnünk arra, hogy milyen hatással voltak a 2018-ban kivetett elsődleges és másodlagos szankciók az iráni gazdaságra. Bijan Khajehpour szerint az nemcsak hogy nem omlott össze, de 2020-ra többé-kevésbé sikerült alkalmazkodnia a helyzethez, amit az 1,7 százalékos gazdasági növekedés is igazol. Eleinte azonban súlyosan romlot tak a viszonyok: a kormányzatnak a riál árfolyamára vonatkozó reformja kudarcot vallott, az infláció ismét kétszámjegyűvé vált, valamint stagfláció alakult ki, és az életszínvonal csökkent (Khajehpour, 2019, 10-12. o.). Az iráni olajexport nemzetközi korlátozásával kapcsolatos amerikai törekvések pedig összességében sikeresnek tekinthetők. A rövid távú hatások elsősorban annak visszaeső adataiban, a hosszabb távúak pedig az újra elmaradt olajipari beruházásokban, valamint az új technológiák vásárlásának a tilalmában nyilvánulnak meg. 2017-ben az olajexport az évtizedes rekordnak tekinthető, napi 2,5 millió hordós szintet ért el, 2020-ra azonban 400.000 hordó/nap alá esett vissza (EIA. U.S. Energy Information Administration, 2021). Az amerikai másodlagos szankciók ellenére Kína - közvetítőkön keresztül - továbbra is importál kisebb mennyiségben iráni olajat. Ennek a haszna azonban a közvetítő vállalatok jelentős költsége miatt rendkívül alacsony. Irán tehát berendezkedett a szankciókra, miközben a gazdaság a nélkül is jelentősebb strukturális reformokra szorulna. 


\section{Külïgyi Szemle}

\section{Konklúzió}

A tanulmány alapján a szankciók elméletére vonatkozóan számos következtetést levonhatunk. Közüilük a legfontosabbak az alábbiak:

1. Az általánosabb jellegủektől az ún. célzott vagy okos szankciók irányába történő elmozdulás figyelhető meg, amelyek politikusokat, üzletembereket, vállalatokat, valamint bizonyos iparágakat céloznak meg.

2. A multilaterális nyomásgyakorlás mindig hatékonyabb, mintha egyetlen állam alkalmaz szankciókat.

3. A szankciók hatékonyságának a mérésével a szakirodalom még napjainkban is adós.

4. A szankcióknak általában kereskedelemelterelỏ hatásuk van.

5. Az utóbbi években elterjedt a nagyhatalmak által alkalmazott másodlagos szankciók rendszere. Ezek hatékonyabbnak bizonyulnak ugyan, ám a nemzetközi jogi státusuk, legitimitásuk megkérdőjelezhető.

A közel-keleti térség kapcsán megállapítható, hogy a hidegháború óta ott alkalmazta az Egyesült Államok a legszélesebb nyomásgyakorló intézkedéseket. A szankciós rezsim időközben jelentős mértékben fejlődött, átalakult: ugyanis míg azokban az években szélesebb körủ, általános szankciókat foganatosítottak, addig napjainkban célzott intézkedéseket tesznek az államok. Líbia kapcsán azt láthattuk, hogy a multilaterális szankcióknak hatásuk volt a gazdaságra, és a Kaddáfirezsimet a nyitásra ösztönözte. Iránban - különösen a másodlagos szankciók alkalmazása következtében - a korábbiaknál is erőteljesebb nyomás nehezedik a rezsimre, ugyanakkor a gazdasági szerkezet és a reziliencia jelentósen befolyásolja az alkalmazkodóképességet. Az iráni gazdaság ugyanis 2020-ra - úgymond - hozzászokott a szankciókhoz, a rezsim összeomlása pedig elmaradt. 
A másodlagos szankciók kérdése tágabb világpolitikai összefüg gésrendszerbe is helyezhető. Az iráni esetben láthattuk, hogy azok fő ként kínai vállalatokat érintenek. Nemzetközi jogi szempontból mind ez ugyanakkor számos kérdést felvet, amelyek messze meghaladják a jelen tanulmány kereteit (Meyer, 2009).

\section{Irodalomjegyzék}

Boone, Peter, Gazdar, Haris és Hussain, Athar (1997). Sanctions Against Iraq.

Costs of Failure. Uniled Nations, Center for Social and Economic Rights. A letöltés ideje: 2021. szeptember 15. https:/cesr.org/sites/default/files/ Sanctions_Against_Iraq_Costs_of_Failure_1997.pdf.

Center for Operational Analysis and Research (2020). Cash Crash: Syria's Economic Collapse and the Fragmentation of the State. A letöltés ideje: 2021. szeptember 15. https://reliefweb.int/sites/reliefweb.int/files/ resources/Cash-crash-Svria\%E2\%80\%99s-economic-collapse-andthe-fragmentation-of-the-state.pdf.

Cockett, Richard (2010). Sudan: Darfur, Islamism, and the World. London: Yale University Press.

Coles, Isabel (2013). Iran's Rouhani Says Economic Problems Go Beyond Sanctions. Reuters. A letöltés ideje: 2021. szeptember 15. https://www. reuters.com/article/us-iran-economv-idINBRE9AOOAU20131127.

Congressional Research Service (2021). State Sponsors of Acts of International Terrorism - Legislative Parameters: In Brief. A letöltés ideje: 2021. szeptember 15. https://s3.documentcloud.org/documents/20697573/ state-sponsors-of-acts-of-international-terrorism-legislativeparameters-in-brief-mav-4-2021.pdf.

Duursma, Allard és Müller, Tanja R. (2019). The ICC Indictment Against al-Bashir and Its Repercussions for Peacekeeping and Humanitarian Operations in Darfur. Third World Quarterly, 4O(5), 890-907.

EIA. U.S. Energy Informalion Administration (2021). Iran's Crude Oil Production Fell to an Almost 40-Year Low in 2020. A letöltés ideje: 2021. október 7. https://www.eia.gov/todavinenergy/detail.php?id=49116. 


\section{Külïgyi Szemle}

Eland, Ivan és Lee, Daniel (2001). The Rogue State Doctrine and National Missile Defense. Calo Instilule, Foreign Policy Briefing, 65. A letöltés ideje: 2021. október 10. https://www.cato.org/sites/cato.org/files/pubs/ $\mathrm{pdf} / \mathrm{fpb} 65 . \mathrm{pdf}$.

Erästö, Tytti (2020). European Non-Proliferation Diplomacy in the Shadow of Secondary Sanctions. SIPRI Policy Brief. A letöltés ideje: 2021. október 21. https://www.sipri.org/sites/default/files/2020-08/pb_2008 instex.pdf.

Fórián-Szabó Viktor és Kovács Tamás (2021). Terhelő örökség. Az iráni gazdaság lehetőségei és kihívásai a 2021-es elnökválasztás után. Külügyi Szemle, 20(3), 38-79.

Galtung, Johan (1967). On the Effects of International Economic Sanctions. With the Examples from the Case of Rhodesia. World Politics, 19(3), $378-416$.

Ghodsi, Mahdi és Karamelikli, Hüseyin (2020). The Impact of Sanctions Imposed by the European Union Against Iran on Their Bilateral Trade: General Versus Targeted Sanctions. The Vienna Instilute for International Economic Studies, Working Paper, 181. A letöltés ideje: 2021. szeptember 15. https:/www.econstor.eu/bitstream/10419/223086/1/ wiiw-wp-181.pdf.

Habibi, Nader (2018). The Iranian Economy Two Years After the Nuclear Agreement. Crown Center for Middle East Studies, Brandeis University, Middle East Brief, 115. A letöltés ideje: 2021. szeptember 15. https:// www.brandeis.edu/crown/publications/middle-east-briefs/pdfs/101200/mebl15.pdf.

Hecker, Siegfrid S. (2010). Lessons Learned from the North Korean Nuclear Crisis. Daedalus, 139(1), 44-56. A letöltés ideje: 2021. október 7. https:// www.amacad.org/sites/default/files/daedalus/downloads/Wi2010_Onthe-Global-Nuclear-Future-Vol-2.pdf.

Homolar, Alexandra (2011). Rebels Without a Consience: The Evolution of the Rogue State Narrative in U.S Security Policy. European Journal of International Relations, 17(4), 705-727.

Hufbauer, Gary Clyde, Schott, Jeffrey J. és Elliott, Kimberly Ann (1990). Economic Sanctions Reconsidered: History and Current Policy. Washington D.C.: Institute for International Economics.

Jentleson, Bruce W. és Whytock, Christopher A. (2005). Who "Won" Libya? The Force Diplomacy Debate and Its Implications for Theory and Policy. International Security, 30(3), 47-86. 
Kaempfer, William H. és Lowenberg, Anton D. (2007). The Political Economy of Economic Sanctions. In Sandler, Todd és Hartley, Keith (szerk.). Handbook of Defense Economincs, Defense in a Globalized World. Vol. 2. (868-911. o.).

Katzmann, Kenneth (2019). Iran Sanctions. CRS Report, RS20871. A le töltés ideje: 2021. szeptember 15. https://www.everycrsreport.com/ files/20191115 RS20871_84b40bd275f6ce5988354065f35bb900clb17c 9c.pdf.

Kausch, Kristina (2015). Competitive Multipolarity in the Middle East. The International Spectator, 5(3), 1-15.

Khajehpour, Bijan (2019). Impact of U.S. Sanctions on the Iranian Economy. In Vogt, Achim és Jalilvand, David (szerk.). One Year After the ReImposition of Sanctions. A letöltés ideje: 2021. szeptember 7. https:// librarv.fes.de/pdf-files/iez/15761.pdf. 11-16. o.

Kreutz, Joakim (2005). Hard Measures by a Soft Power? Sanctions Policy of the European Union 1981-2004. Bonn: Bonn International Center for Conversion. A letöltés ideje: 2021. október 7. https:/www.bicc.de/ uploads/tx_bicctools/paper45.pdf.

Malik, Mohamed és Malik, Malik (2015). The Efficacy of United States Sanctions on the Republic of Sudan. Journal of Georgelown Universily - Oatar Middle Eastern Studies Student Associalion, 7. A letöltés ideje: 2021. szeptember 15. https:/www.qscience.com/docserver/fulltext/

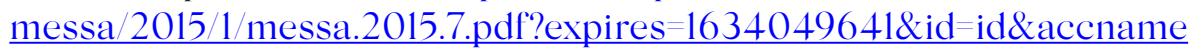
guest\&checksum=19EC90DD78DA8F61817C0437AE991EOE.

Meyer, Jeffrey A. (2009). Secondary Thoughts on Secondary Sanctions. University of Pennsylvania Journal of International Law, 30(3), 905-968. Middle East Instilute (2016). Iran's Big Asian Oil Customers Return. A letöltés ideje: 2021. október 10. https://www.mei.edu/publications/iransbig-asian-oil-customers-return.

Mousavian, Seyed Hossein (2021). The Iran Nuclear Deal Is Not Dead. Here Is How It Can Be Revived. Middle East Eye. A letöltés ideje: 2021. október 21. https://www.middleeasteve.net/opinion/iran-nuclear-dealnot-dead-how-revived.

N. Rózsa Erzsébet (2008). Az iráni atomvita. Nemzel és Bizlonság, 9, 19-27.

N. Rózsa Erzsébet (2021). A Közel-Kelet nukleáris kérdései - középpontban az iráni nukleáris program. Külügyi Szemle, 20(3), 145-170.

N. Rózsa Erzsébet és Szigetvári Tamás (2019). The Resistance Economy: Iranian Patriotism and Economic Liberalisation. In Gerőcs Tamás és 


\section{Külïgyi Szemle}

Szanyi Miklós (szerk.), Market Liberalism and Economic Patriolism in the Capilalist World System. Cham: Palgrave Macmillan. (169-182. o.).

Nephew, Richard (2018). Libya: Sanctions Removal Done Right? A Review of the Libyan Sanctions Experience, 1980-2006. Columbia SIPA, Center on Global Energy Policy. A letöltés ideje: 2021. október 5. https:/energypolicy.columbia.edu/sites/default/files/pictures/Libya\%20 Sanctions\%20Removal_CGEP_Report_031918.pdf.

Newnham, Randall (2010). North Korea, Libya, and Iran: Economic Sanctions and Nuclear Proliferation. Korea Economic Instilute, Academic Paper Series, 5(7). A letöltés ideje: 2021. szeptember 7. https://keia.org/wpcontent/uploads/2020/05/APS-Newnham-2010.pdf.

Ramani, Samuel (2021). Spotlight on Sudan. Konrad Adenauer Stifiung, (2). A letöltés ideje: 2021. szeptember 15. https://www.kas.de/ documents $/ 282499 / 282548 /$ Spotlight + on + Sudan +-+ June +2021 . pdf/ff50aef $8-3 \mathrm{del}-3 \mathrm{c} 29-12 \mathrm{a} 6-\mathrm{d} 838 \mathrm{a} 1165937$ ? version $=1.1$ \& $\mathrm{t}=1623752034766$.

Rennack, Dianne E.(2005). Sudan: Economic Sanctions. CRS Reporl for Congress. A letöltés ideje: 2021. szeptember 15. https://www. everversreport.com/files/20020521_RL32606_Od80ed70253743f877a 544f6c2bee343be9e05c7.pdf.

Ronen, Yehudit (2008). Qaddhafi's Libya in World Politics. Boulder, CO. és London: Lynne Rienner Publishers.

Ruys, Tom és Ryngaert, Cedric (2020). Secondary Sanctions: A Weapon Out of Control? The International Legality of, and European Responses to, US Secondary Sanctions. Brilish Yearbook of International Law. Oxford: Oxford University Press. 1-116. o.

Schwartz, Jonathan B. (2007). Dealing with a "Rogue State": The Libya Precedent. The American Journal of International Lav, IOI(553), 553 580.

Smeets, Maarten (2018). Can Economic Sanctions Be Effective? WTO Slaff Working Paper, (3). A letöltés ideje: 2021. október 1. https://www. econstor.eu/bitstream/10419/176768/1/1016551045.pdf.

St John, Ronald Bruce (2004). "Libya Is Not Iraq": Preemptive Strikes, WMD, and Diplomacy. Middle East Journal, 58(3), 386-402.

Sultoon, Samantha és Walker, Justine (2019). Secondary Sanctions' Implications and the Transatlantic Relationship. Allantic Council, Issue Brief. A letöltés ideje: 2021. október 4. https://www.atlanticcouncil.org/ wp-content/uploads/2019/09/SecondarvSanctions_Final.pdf. 
The Carler Center (2020). U.S. and European Sanctions on Syria. A letöltés ideje: 2021. szeptember 15. https://www.cartercenter.org/resources/pdfs/ peace/conflict_resolution/svria-conflict/us-and-european-sanctionson-svria-091620.pdf.

The World Bank (2017). Iran Economic Monitor, Fall 2017. Sustaining Growth: The Challenge of Job Creation. A letöltés ideje: 2021. szeptember 15. http://hdl.handle.net/10986/29440.

The World Bank (2021). Iran. A letöltés ideje: 2021. október 10. https://data. worldbank.org/indicator/NY.GDP.MKTP.KD.ZG?locations=IR.

Toubman, Daniel (2021). International Law Implications of the JCPOA: Where Do We Go from Here? Michigan Journal of International Law, 42. A letöltés ideje: 2021. október 21. http://www.mjilonline.org/ international-law-implications-of-the-jcpoa-where-do-we-go-fromhere/.

Toumaj, Amir (2014). Iran's Economy of Resistance: Implications for Future Sanctions. American Enterprise Instilute Report. A letöltés ideje: 2021. szeptember 15. https://www.criticalthreats.org/wp-content/ uploads/2016/07/imce-imagesToumajA Irans-Resistance-EconomyImplications november2014-1.pdf.

Verjee, Aly (2018). Sudan After Sanctions. Uniled Stales Instilute of Peace, Special Report, (427). A letöltés ideje: 2021. szeptember 15. https:// www.usip.org/sites/default/files/2018-05/sr427-sudan-after-sanctionssudanese-views-of-relations-with-the-united-states.pdf.

Wallensteen, Peter, Staibano, Carina és Eriksson, Mikael (2005). The 2004 Roundtable on the UN Sanctions Against Iraq: Lessons Learned. Uppsala: Uppsala University, Department of Peace and Conflict Research. 